\title{
Nongranulomatous interstitial lung disease in Crohn's disease
}

\author{
G. Hotermans*, A. Benard*, H. Guenanen*, G. Demarcq-Delerue**, \\ T. Malart ${ }^{+}$, B. Wallaert*
}

Nongranulomatous interstitial lung disease in Crohn's disease. G. Hotermans, A. Benard, H. Guenanen, G. Demarcq-Delerue, T. Malart, B. Wallaert. CERS Journals Ltd 1996. ABSTRACT: Crohn's disease is a granulomatous systemic disorder of unknown aetiology. Obvious pulmonary involvement is exceptional. We report the case of a 33 year old woman treated with mesalazine for Crohn's disease and presenting with dyspnoea.

Pulmonary function tests showed a restrictive ventilatory pattern with hypoxaemia on exertion. Chest radiography disclosed an interstitial pattern with ground glass on high resolution computer tomography. Clinical and radiological abnormalities progressed after withdrawal of mesalazine. Corticosteroids led to a partial regression but were stopped because of severe side-effects.

Because of worsening of the clinical situation, open lung biopsy was performed and showed a histopathological aspect of nongranulomatous interstitial diffuse lung disease with an inflammatory lymphoid infiltration associated to some mild interstitial collagen fibrosis. Addition of cyclophosphamide to high-dose pulse steroid therapy induced a significant and sustained improvement.

Eur Respir J., 1996, 9, 380-382.
* Service de Pneumologie et Immunoallergologie, Hôpital Calmette, Lille, France. **Clinique Tessier, Valenciennes, France. ${ }^{+}$Cabinet d'Anatomie et de Cytologie Pathologiques, Valenciennes, France.

Correspondence: B. Wallaert

Service de Pneumologie et Immunoallergologie

Hôpital A. Calmette

Bld du Professeur Jules Leclerc 59037 Lille Cedex

France

Keywords: Crohn's disease interstitial lung disease lung

Received: April 211995

Accepted after revision September 71995
Pulmonary involvement is rare in Crohn's disease and was evaluated as $0.4 \%$ in a study concerning 1,400 patients [1]. Previous cases of bronchopulmonary associated disease have been described, such as granulomatous interstitial lung disease (ILD) $[2,3]$. We report the case of a patient with Crohn's disease, who developed a fibrosing nongranulomatous ILD.

\section{Case report}

A 33 years old woman was admitted in October 1991 for chronic cough and dyspnoea on exertion. Since 1988, she had been treated with mesalazine (Pentasa ${ }^{\circledR}$ ) for Crohn's disease. Clinical examination revealed disseminated crackles. Chest radiography and high resolution computed tomography (HRCT) showed diffuse groundglass opacities (fig. 1). Pulmonary function tests (PFT) showed a restrictive pattern (vital capacity (VC) 47\% of predicted value, total lung capacity (TLC) $66 \%$ pred). Blood gas showed a moderate hypoxaemia (arterial oxygen tension $\left.\left(\mathrm{Pa}, \mathrm{O}_{2}\right) 10.5 \mathrm{kPa}(79 \mathrm{mmHg})\right)$. On exertion, $\mathrm{Pa}, \mathrm{O}_{2}$ fell (table 1). Blood tests showed a moderate increase of the inflammatory markers: erythrocyte sedimentation rate (ESR) $33 \mathrm{~mm} \cdot \mathrm{h}^{-1} ; \mathrm{C}$ reactive protein $16 \mathrm{mg} \cdot \mathrm{L}^{-1}$; anti deoxyribonucleic acid (DNA) antibodies, circulating immune complexes, antinuclear antibodies, and complement were all normal. Serodiagnostics

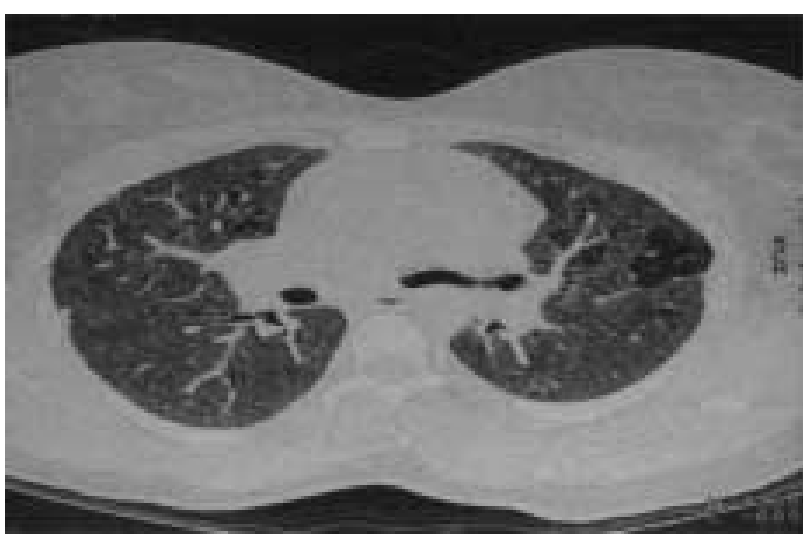

Fig. 1. - High resolution computed tomography (HRCT) scan, showing diffuse ground-glass opacities in both lungs.

for Aspergillus, Candida, and bird breeders' lung were negative. Angiotensin converting enzyme (ACE) was increased to $53 \mathrm{nmol} \cdot \mathrm{mL}^{-1}$. The only abnormality was an increased immunoglobulin (IgE) level of $693 \mathrm{KIU} \cdot \mathrm{L}^{-1}$.

Bronchoalveolar lavage (BAL) showed 705,000 cells $\cdot \mathrm{mL}^{-1}$ in $78 \mathrm{~mL}$, with $54 \%$ macrophages, $23 \%$ lymphocytes, 14\% neutrophils and 9\% eosinophils [4]. Transbronchial biopsies revealed an inflammatory mononuclear cell infiltrate. Biopsy of minor salivary glands was normal.

Mesalazine was withdrawn in November 1991 without any improvement, and corticotherapy $0.5 \mathrm{mg} \cdot \mathrm{kg}^{-1}$ q.d. 


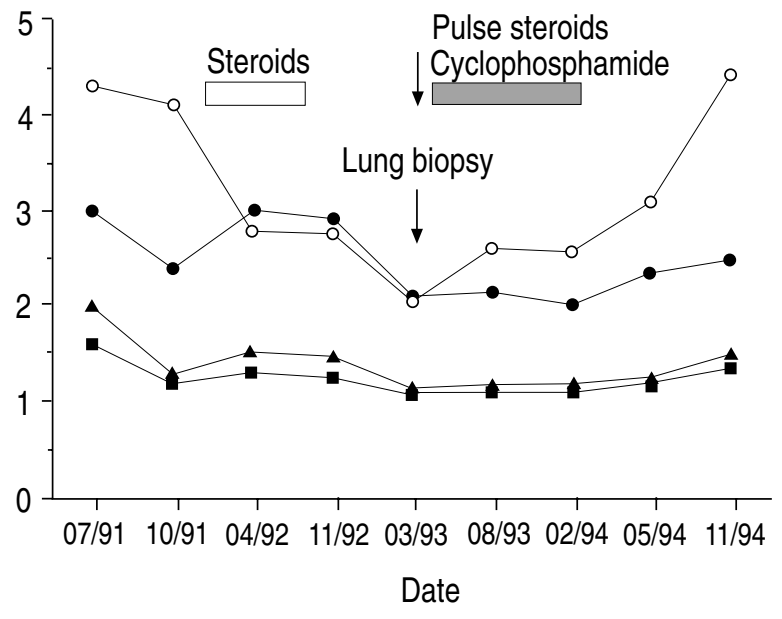

Fig. 2. - Evolution of the pulmonary function tests. $-\bullet$ : total lung capacity $(\mathrm{L}) ;-\square$ : forced vital capacity $(\mathrm{L})$; $\square$ : forced expiratory volume in one second $(\mathrm{L}) ; \quad \longrightarrow-$ : transfer factor of the lungs for carbon monoxide $\left(\mathrm{mL} \cdot \mathrm{min}^{-1} \cdot \mathrm{mmHg}^{-1} \cdot \mathrm{L}\right)$.

was initiated in January 1992. Four months later, the patient was feeling better. Oximetry on exertion had improved (table 1), the ventilatory defect was less marked (fig. 2), and tomodensitometry showed a mild regression of the ground-glass opacities. BAL was repeated and showed 527,000 cells $\cdot \mathrm{mL}^{-1}$ in $74 \mathrm{~mL}$, with $56 \%$ macrophages, $29 \%$ lymphocytes, 5\% neutrophils and $10 \%$ eosinophils. However, despite the respiratory improvement, the patient wished to stop the corticotherapy in May 1992 because of uncomfortable side-effects, such as extensive acne and excessive facial hair. The dyspnoea rapidly increased, with asthenia, extension of the ground-glass opacities to the whole parenchyma, and worsening of the ventilatory tests.

Open lung biopsy was performed and showed an inflammatory lymphoid infiltration, essentially in the interalveolar walls and irregularly within the airspaces, with eosinophils and macrophages but without any granulomatous lesions (fig. 3). There was some interstitial collagen fibrosis and bronchioles contained some mucoid retention but the pleura and the vessels had a normal aspect.

Because of these histological appearances, corticotherapy was restarted, this time as high-dose pulse $\left(30 \mathrm{mg} \cdot \mathrm{kg}^{-1}\right.$ a)

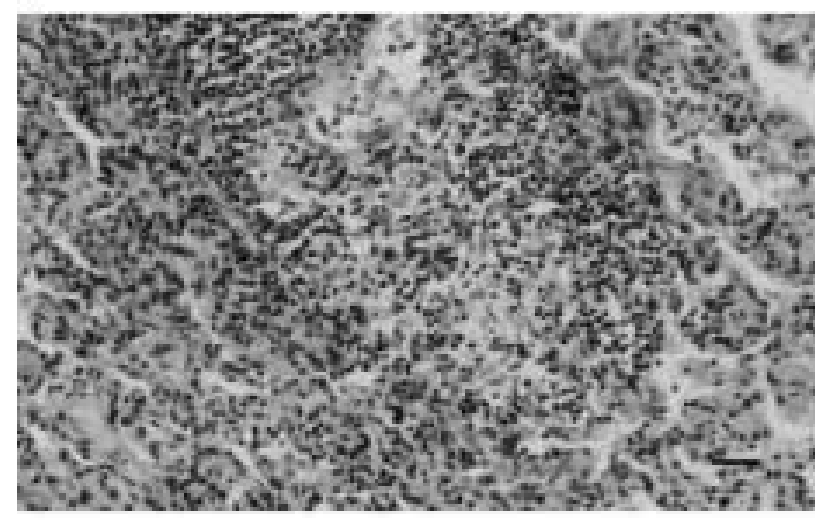

b)

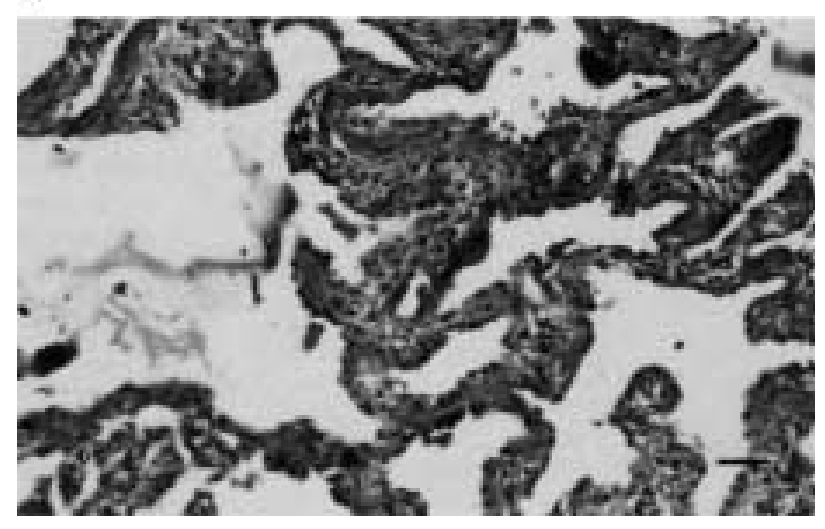

Fig. 3. - Pathological findings on the pulmonary parenchyma biopsy. a) Inflammatory lymphoid interalveolar infiltration; bronchi and vessels had a normal aspect. (Haematoxylin and eosin stain; internal scale $\mathrm{bar}=50 \mu \mathrm{m})$; b) Some interstitial collagen fibrosis without granulomatous lesions (Trichrome stain; internal scale bar $=50 \mu \mathrm{m}$ ).

once a week for 6 weeks), in order not to induce a recurrence of the side-effects. Long-term therapy was then added with cyclophosphamide $\left(100 \mathrm{mg} \cdot \mathrm{day}^{-1}\right)$. The evolution was favourable with progressive clinical and functional improvement (table 1). Immunosuppressive therapy was stopped in February 1994. A new clinical and functional evaluation was performed in November 1994, showing a sustained improvement without significant radiological changes.

Table 1. - Sequential evaluation of clinical exercise testing

\begin{tabular}{|c|c|c|c|c|c|c|c|c|}
\hline \multirow[t]{2}{*}{ Date } & \multicolumn{3}{|c|}{ At rest } & \multicolumn{5}{|c|}{ On exertion } \\
\hline & $\begin{array}{l}\mathrm{Pa}, \mathrm{O}_{2} \\
\mathrm{kPa}\end{array}$ & $\begin{array}{c}{\mathrm{Sa}, \mathrm{O}_{2}}_{\%} \\
\%\end{array}$ & $\begin{array}{c}P(\mathrm{~A}-\mathrm{a}), \mathrm{O}_{2} \\
\mathrm{kPa}\end{array}$ & $\begin{array}{c}\text { Effort } \\
W\end{array}$ & $\begin{array}{c}P \mathrm{a}, \mathrm{O}_{2} \\
\mathrm{kPa}\end{array}$ & $\begin{array}{c}{\mathrm{Sa}, \mathrm{O}_{2}}_{\%} \\
\%\end{array}$ & $\begin{array}{c}P(\mathrm{~A}-\mathrm{a}), \mathrm{O}_{2} \\
\mathrm{kPa}\end{array}$ & $\begin{array}{c}V^{\prime} \mathrm{O}_{2} \\
\mathrm{~mL} \cdot \mathrm{min}^{-1} \cdot \mathrm{kg}^{-1}\end{array}$ \\
\hline $11 / 91$ & 10.5 & 96 & ND & 40 & 6.4 & 84 & ND & ND \\
\hline $04 / 92$ & 14.4 & 98 & ND & 40 & 9.7 & 94 & ND & ND \\
\hline $11 / 92$ & 12.9 & 98 & ND & 40 & 7.6 & 89 & ND & ND \\
\hline 03/93 & 11.6 & 94 & 3.9 & 55 & 7.6 & 86 & 8.0 & 14 \\
\hline 08/93 & 10.5 & 93 & 3.7 & 80 & 6.9 & 82 & 9.2 & 19.7 \\
\hline 02/94 & 11.0 & 95 & 2.9 & 80 & 6.8 & 83 & 7.6 & 14.8 \\
\hline $11 / 94$ & 11.2 & 94 & 1.9 & 80 & 7.4 & 86 & 7.6 & 20 \\
\hline
\end{tabular}

$\mathrm{Pa}_{\mathrm{a}} \mathrm{O}_{2}$ : arterial oxygen tension; $\mathrm{Sa}_{\mathrm{a}} \mathrm{O}_{2}$ : arterial oxygen saturation; $\mathrm{P}(\mathrm{A}-\mathrm{a}), \mathrm{O}_{2}$ : alveolar to arterial difference in oxygen tension; $V^{\prime} \mathrm{O}_{2}$ : oxygen consumption; ND: not determined. 


\section{Discussion}

This case may be considered as pulmonary fibrosing alveolitis occurring in Crohn's disease. Although one cannot exclude that previous steroid therapy had altered the histological pattern of the lung parenchyma, the pathological characteristics of this observation were a thickening of the alveolar wall by collagen fibrosis and an inflammatory lymphoid infiltration without any granulomatous lesion. This observation clearly differs from granulomatous pulmonary involvement occurring in Crohn's disease, consisting of noncaseating epithelioid granuloma with multinucleated giant cells in the interstitium and in the peribronchiolar and perivascular regions. These granulomatous, sarcoid-like lesions are not specific and may be considered either as pulmonary involvement in Crohn's disease or as an unknown sarcoidosis with intestinal involvement [5-10]. A few cases of pulmonary parenchymal involvement in Crohn's disease have been reported, including seven cases of interstitial lung fibrosis [11-13], one case of alveolar consolidation [14], one case of bronchiolitis obliterans organizing pneumonia (BOOP) [2] and one case of lung infiltrates with peripheral eosinophilia [2]. Among the seven patients suffering from Crohn's disease with radiological and clinical signs of ILD, open lung biopsies were performed in only two cases. The alterations were similar, showing acute alveolitis, granulomatous lymphocytic infiltration of the interstitium and of the walls of small arteries, with slight interstitial fibrosis. In four patients, no biopsy was performed, and in the last one, bronchial biopsy did not reveal any specific lesion. In the case of alveolar consolidation of the left lower lobe, the open lung biopsy showed multiple focal areas of noncaseating epithelioid granuloma containing multinucleated giant cells in the interstitium. Lastly, in the case of pulmonary infiltrates and eosinophilia, the open lung biopsy revealed interstitial and airspace infiltration by eosinophils and an oedematous thickening of the septa. These aspects were all different from the lesions observed in our observation.

The main problem when interstitial lung disease occurs in the course of systemic disorders is to exclude druginduced lung disease, in our case mesalazine-associated pneumonitis. Only two cases of mesalazine-induced lung disease have previously been reported $[15,16]$, with a rapid improvement after mesalazine withdrawal. In our case, ILD worsened after withdrawal of the drug and PFT deteriorated after steroid withdrawal.

Interestingly, the outcome of interstitial lung disease was favourable using a combination of steroids and cyclophosphamide. Pulmonary manifestations of inflammatory bowel disease usually respond dramatically to inhaled and/or systemic steroids [2] The addition of cyclophosphamide in our case allowed a sustained beneficial effect, as was recently demonstrated in the course of patients with idiopathic pulmonary fibrosis [17]. Taken together, these findings suggest that nongranulomatous interstitial lung disease mimicking idiopathic pulmonary fibrosis may occur during the course of Crohn's disease.

\section{References}

1. Rodgers BH, Clark LM, Kirsner YB. The epidemiologic and demographic characteristics of inflammatory bowel disease: an analysis of a computerized file of 1,400 patients. J Crohn Dis 1971; 24: 743-753.

2. Camus Ph, Piard F, Ashcroft Th, Gal AA, Colby TV. The lung in inflammatory bowel disease. Medicine (Baltimore) 1993; 72: 151-183.

3. Wallaert B, Marchand E. Manifestations respiratoires de la maladie de Crohn. Editions Techniques. Encycl Med Chir Pneumol 1994; 6062-D-20: 2 p.

4. Report of the European Society of Pneumology Task Group on BAL. Technical recommendations and guidelines for bronchoalveolar lavage. Eur Respir J 1989; 2: 561-585.

5. Calder CJ, Lacy D, Raafat F, Weller PH, Booth IW. Crohn's disease with pulmonary involvement in a 3 year old boy. Gut 1993; 34: 1636-1638.

6. Dines DE, De Remee RA, Green PA. Sarcoidosis associated with regional enteritis (Crohn's disease): report of two cases. Min Med 1971; 54: 617-620.

7. Kraft SC. Crohn's disease and sarcoidosis. N Engl J Med 1971; 285: 1259-1260.

8. MacCormick PA, O'Donoghue DP, Fitzgerald Mx. Crohn's colitis and sarcoidosis. Post Grad Med J 1986; 62: 951-953.

9. Padilla AJ, Sparberg M. Regional enteritis and sarcoidosis in one patient. Gastroenterology 1972; 63: 153.

10. Shah SM, Texter EC, White HJ. Inflammatory bowel disease associated with granulomatous lung disease: report of a case with endoscopic findings. Gastrointest Endoscopy 1976; 20: 442-443.

11. Heatley RV, Thomas P, Prokipchuk EJ, Gauldie J, Sieniewicz DJ, Bienenstock J. Pulmonary function abnormalities in patients with inflammatory bowel disease. $Q$ J Med 1982; 203: 241-250.

12. Henrion F, Bretagne MC, Neimann L, Flechon PE, Canton $\mathrm{Ph}$, Hoeffel JC. Association exceptionnelle de lésions pulmonaires, cutanées et d'une ilélite terminale chez un enfant de 11 ans. J Radiol 1982; 63: 123-126.

13. Kayser K, Probst F, Gabius HJ, Muller KM. Are there characteristic alterations of lung tissue associated with Crohn's disease? Pathol Res Pract 1990; 186: 485-490.

14. Puntis JWL, Tarlow MJ, Raafat F, Weller PH, Booth IW. Crohn's disease of the lung. Arch Dis Child 1990; 65: 1270-1271.

15. Reinoso MA, Schroeder KN, Pisani RJ. Lung disease associated with orally-administered mesalazine for ulcerative colitis. Chest 1992; 101: 1469-1470.

16. Declerck D, Wallaert B, Demarcq-Delerue G, Tonnel AB. Pneumopathie interstitielle diffuse iatrogène liée au 5-aminosalicylate. Rev Mal Respir 1994; 11: 292-293.

17. Van Oorteghem D, Wallaert B, Marquette $\mathrm{CH}$, et al. Determinants of response to immunosuppressive therapy in idiopathic pulmonary fibrosis. Eur Respir J 1994; 11: 1950-1957. 